\title{
Bacillus-based nano-bioformulations for phytopathogens and insect-pest management
}

\author{
Pradeep Kumar ${ }^{1^{*}} \mathbb{D}$, Shikha Pandhi ${ }^{2}$, Dipendra Kumar Mahato ${ }^{3}$, Madhu Kamle ${ }^{1}$ and Archana Mishra ${ }^{4}$
}

\begin{abstract}
Background: Recent concerns linked with the application of chemical pesticides and the increasing necessity of low inputs sustainable agriculture have put the use of microbial biocontrol agents and bio-pesticides to the forefront for their application against plant pathogens and insect-pest management.

Results: This review tended to scrutinize the prospects of microbial biocontrol agents and microbes-based nano-formulations against plant diseases and for pest management with emphasis on bacteria-based nanoparticles, especially derived from Bacillus species. It also tended to discuss the probable mechanism of action and effect on plant growth along with its prospects in a brief manner.

Conclusion: The use of microbial biocontrol agents offers effective, eco-friendly, and long-lasting management of plant diseases. The employment of nanotechnology in the field of biopesticides has emerged as a promising solution. Nano-biopesticides in the form of biologically derived active pesticides or compounds integrated as nanoparticles and integrated into a suitable polymer have application in insect-pest management.
\end{abstract}

Keywords: Bacillus sp., Biocontrol, Nanoparticles, Phytopathogens, Insect-pest management

\section{Background}

To meet the escalating need for food demand and security, it is essential to improve the agricultural yields to meet growing population requirements. The control of diseases stands obligatory to safeguard human food sources and agricultural outputs (Syed et al. 2018). Currently, there is a robust thrust towards the development of more sustainable agricultural practices with much lower input. Among these agricultural practices utilizing sustainable alternatives to chemicals for pest and disease management have attained immense potential to alleviate substantial losses of agricultural produce. The alarming adverse effects of conventional

\footnotetext{
*Correspondence: pkbiotech@gmail.com

1 Applied Microbiology Laboratory, Department of Forestry, North Eastern Regional Institute of Science and Technology, Nirjuli, Arunachal Pradesh 791109, India

Full list of author information is available at the end of the article
}

chemicals used for disease and pest management on public health, the environment, and living microorganisms have encouraged researchers to look for a sustainable approach. This has encouraged the exploration of microbial biocontrol agents as a viable alternative for the insect-pest management (Syed et al. 2018). Microbial biocontrol agents offer control over plant diseases and pests by suppressing the plant pathogens' growth using living microorganisms (Köhl et al. 2019). Microbial biocontrol agents defend agricultural products from insect/pest damage through the various mechanism of action including the antagonistic effect on the pathogen, competitive inhibition, and production of antimicrobial metabolites (Köhl et al. 2019). Bacteria are among the most employed biocontrol agent against plant pathogens and pests. Among these, the genus Bacillus has been extensively explored because of its entomopathogenic potential (Mampallil et al. 2017). Bacillus group of bacteria is an inhabitant of a 
wide number of habitats and is well known with the capability to produce several antimicrobial compounds with varying structures having about $5-8 \%$ of genome responsible for the synthesis of secondary metabolites. Biocontrol ability of Bacillus strains is demonstrated mainly through an inhibitory action against plant pathogens as well as through the induction of systemic resistance to strive for their population dominance over plant pathogens (Fira et al. 2018).

Nanotechnology offers extensive prospects for the development of materials with improved or inventive functionalities of nano-sized materials and substances due to its much larger surface area. The use of nano-sized materials as the carrier of active ingredients or carriers in the field of pesticides has resulted in improved efficiency in regard to the application as well as dosages required (Devi et al. 2019). The conventional approaches like integrated pest management employed in agricultural practices are insufficient, thereby, creating a demand for alternatives. In this regard, nanotechnology fulfils the demand as an eco-friendly alternative insect-pests management (Bhattacharyya et al. 2016). It is highly employed for the protection of pesticides from hostile environmental factors such as temperature and radiation with considerably improved chemical stability. It enhances the dispensability and wettability of the pesticide formulation and provides a smart delivery system with a controlled release at the targeted site (Kumar et al. 2019a). The recent upsurge of commercial interest in Bacillus thuringiensis (Bt) has led to enhanced and efficacious formulations. However, its application in the form of nanoparticles (NPs) for plant protection is in juvenile stage and requires further exploration. The development of a nano-formulation based on $B t$ is based on top-down approaches of micronization such as ball and jet milling as well as high-pressure homogenization for the transformation of coarse powder to fine particles with a size range of $2-5 \mu \mathrm{m}$. This approach is easy to expand and gives reproducible outcomes, but sometimes may show variation in different batches (Devi et al. 2019). Another important nano-technological approach for insect pest management utilizes the tendency of microbes for the creation of NPs that act antagonistically to pests and insects (Ali et al. 2020).

This review tended to provide an updated review on microbial biocontrol agents and nano-biopesticides as an environmentally benign approach against various phytopathogens and insect pest management. It tended to address various bacteria-based NPs or nano-formulations, especially based on Bacillus species against phytopathogens and insects along with their mode of action. It also discussed the effect on plant growth and promotion along with the prospects.

\section{Main text}

\section{Microbial biocontrol}

The utilization of chemicals to control diseases in economically essential crops has been practised for a long time and is preferred by the farmers due to its low cost and immediate effect. But their associated adverse effects on human life and other living microorganisms and ability to enter the food chain through the accumulation of toxic residues had encouraged the hunt for more sustainable alternatives. The suppression of plant-pathogen species by living microorganisms is known as "biological control" of plant diseases. Controlling plant pests and pathogens using biological agents seems to be the best choice for developing low-cost, environmentally friendly, and long-term management strategies. Biological control is now widely recognized as an important strategy for mitigating plant disease to ensure sustainable agriculture (Syed et al. 2018). Biocontrol agents include preparations consisting of living microorganisms exerting detrimental effects on the pathogen (Sharma et al. 2017). Isolates of beneficial microorganisms with highly potential effectiveness against pathogens can be grown on culture media. This process of selection and production of antagonists in bulk is referred to as "Augmentative biological regulation" (Köhl et al. 2019). Most of these biocontrol agents include predators and parasitoids that are naturally present which offer exceptional regulation of numerous pests and diseases. Biocontrol agents offer tremendous frontiers as a novel approach, either alone or in the combined application (Patibanda and Ranganathswamy 2018). These microbial biocontrol agents offer several advantages safe to the environment and humans, comparatively less expensive than the conventional agents of chemical origin, wide-spectrum effectiveness against soil-borne pathogens with an increased yield of crop by enhancing beneficial microbes' growth. The use of biocontrol agent is self-regulating and does not necessitate any complex management, does not exert any toxic effect on plants, long-term disease management and growth-promoting effect (Fig. 1) (Patibanda and Ranganathswamy 2018).

Microbial control agents work in a variety of ways to protect crops from disease disruption. They have the potential to induce enhanced resistance to pathogen infections without having a strong antagonistic relationship with the pathogen apart from their struggle for food and space as an indirect method of action. As for direct mode, hyper-parasitism or antibiosis can be used to deal directly with the pathogen. Hyperparasites attack and destroy fungal pathogens' mycelia, spores, and resting structures, as well as bacterial pathogens' cells. Another direct method includes the development of antimicrobial secondary metabolites that inhibit pathogens (Köhl 


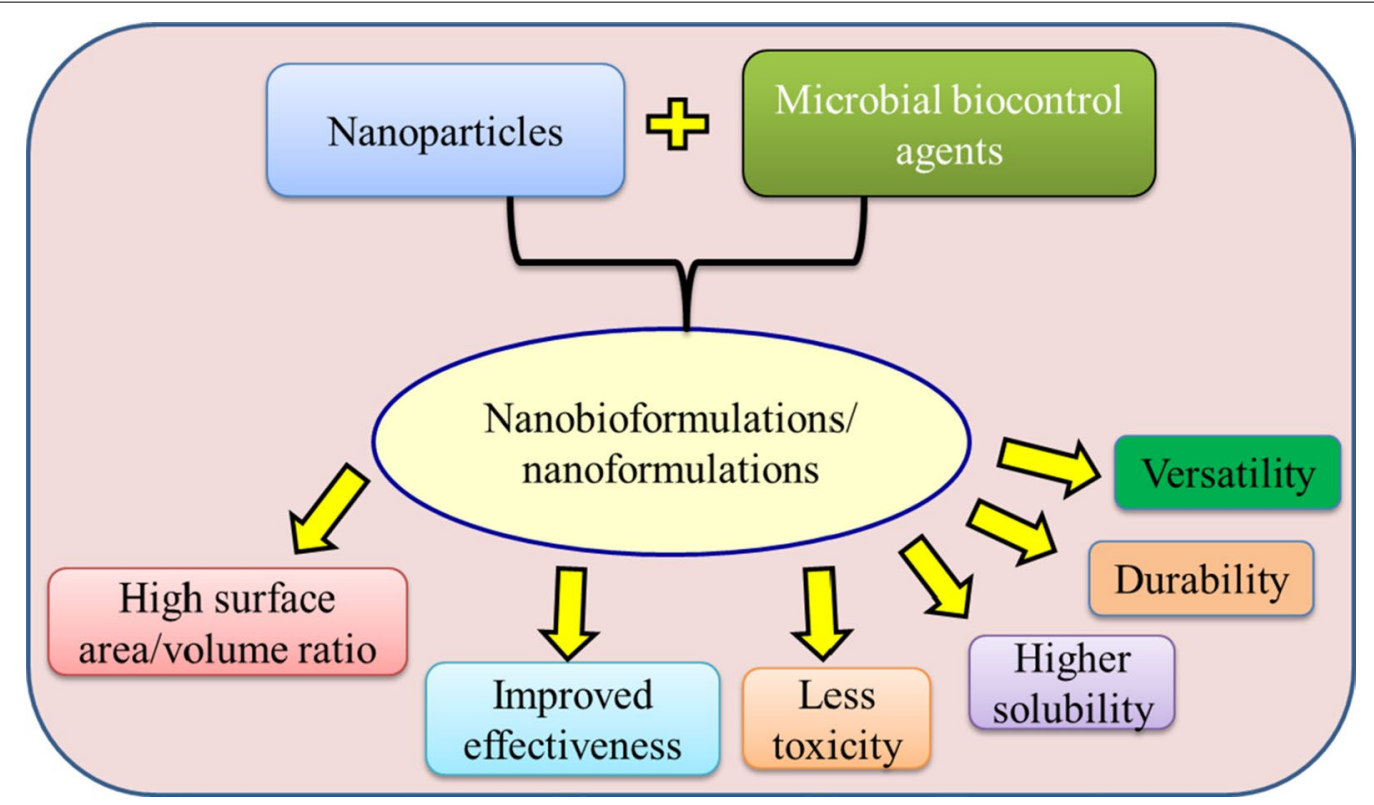

Fig. 1 Advantages of microbial nano-bioformulations for sustainable agriculture

et al. 2019). Antagonists benefit from low levels of secondary metabolites being secreted in situ which help them acquire a competitive lead. In certain cases, biocontrol agents are chosen based on their efficient secondary metabolites production capability in the growth media during mass processing and are used in biological control products alongside or without living antagonist cells. As a result, antagonistic microorganisms can restrict pathogen populations in a variety of ways. The antagonist's mode(s) of action determines more than just how it affects a pathogen population. The microbial biological control agent's characteristics are often influenced based on the mechanism of action employed. The concerns for humans and the environment alongside the development of resistant variety and its reliance on environmental and crop physiological factors may also vary depending on the mechanism of action. Preferences for the specific mechanism of action for a biocontrol agent's intended application would also influence the strategies used to find new antagonists (Fig. 2) (Köhl et al. 2019).

\section{Bacteria-based nano-formulation}

Bacteria are prokaryotic, unicellular organisms of lengths ranging from a few millimeters to several meters. The Bacillaceae, Enterobacteriaceae, Micrococcaceae, Pseudomonadaceae and Streptococcaceae families contain the majority of insect pathogenic bacteria. Bacillaceae members, especially Bacillus spp., have got a lot of attention as microbial control agents. Bacterial biopesticides are among the most used microbial pesticides working in a variety of ways. They are often utilized as insecticides, however, can be employed for the mitigation of pathogenic bacteria and fungi in plants. They must encounter the potential pest and ingestion may be a prerequisite to attain effectiveness. Bacteria present in insects inhibit digestion by developing endotoxins. The bacterial biopesticide colonizes the plant and inhibits the disease-causing bacterial or fungal infestation (Kachhawa 2017). The Bacillaceae, Enterobacteriaceae and Pseudomonadaceae families contain the majority of entomopathogenic bacteria. Entomopathogenic activity is also present in households, but to the least degree. Gram-positive, heterotrophic, rod-shaped bacteria that can create endospores make up the Bacillaceae family. Bacillus thuringiensis, $B$. sphaericus, B. popillae, B. pumilus, Brevibacillus laterosporus, and others are members of this genus (Mampallil et al. 2017). B. thuringiensis (Bt) subspecies and strains are the most commonly used microbial pesticides. $B t$ has been employed for controlling insects and pests in agriculture with its most distinguishing feature that is the formation of crystalline inclusions with insecticidal proteins referred to as "Cry proteins" during sporulation. $B t$ and Cry proteins are considered efficient, reliable, and viable options for insect-pest management (Keswani et al. 2020).

Nanotechnology is a propitious area of interdisciplinary research offering a wide range of applications in the fields of insecticides and agriculture. With growing concerns about the impact of traditional pest management methods on the environment, nanotechnological approaches 


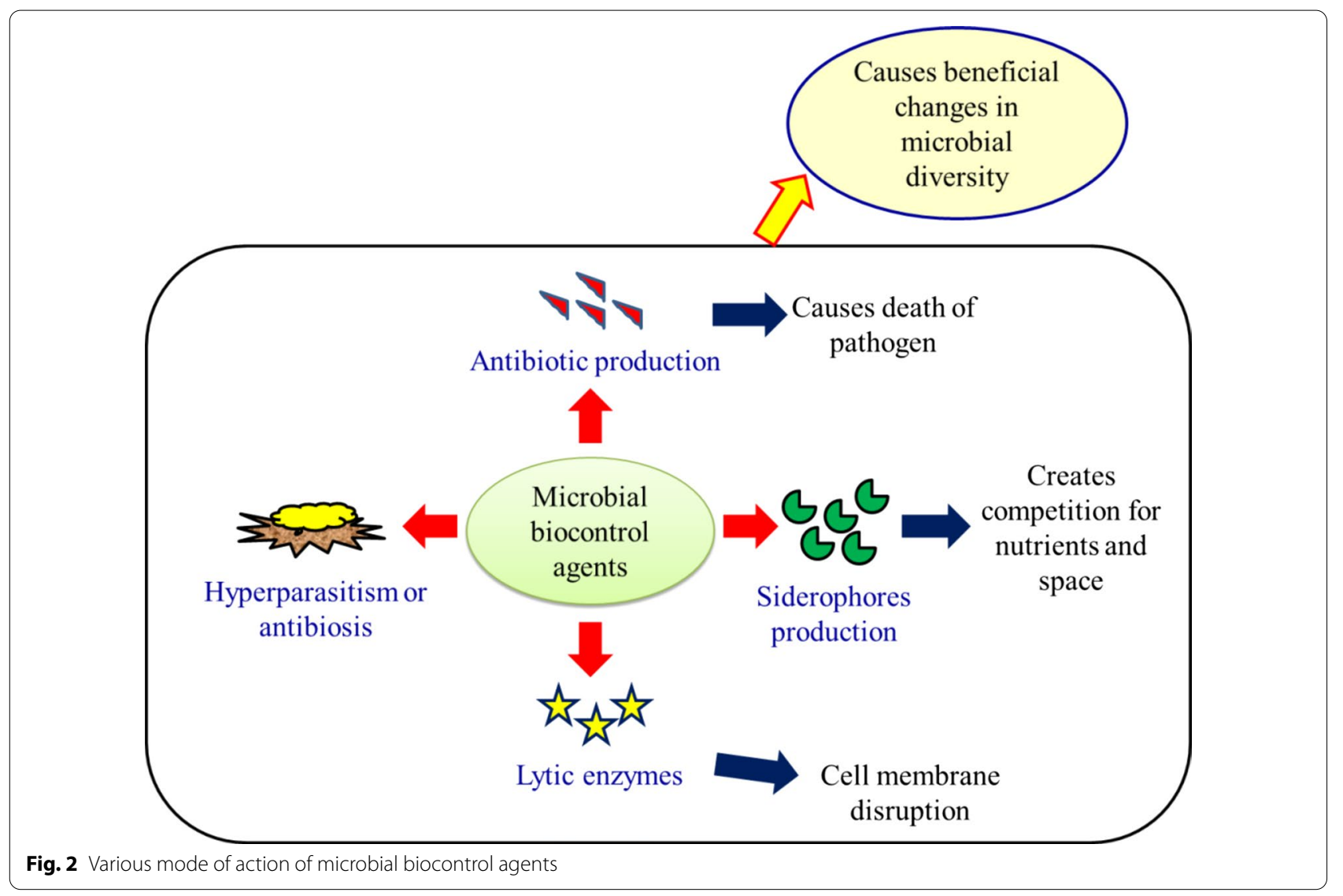

have offered an environment-friendly alternative for insect-pest management with no or little negative impact on natural harmony. Pathogenic fungi including Fusarium spp., Rhizoctonia solani and Phythophora spp. infect the whole plant, while Botrytis cinerea infects fruit tissues and green parts (Bhattacharyya et al. 2016). Nano-formulations of pesticides must have a wide spectrum of advantages such as enhanced efficiency and longevity, better dispersibility and wettability, biodegradable and free of toxicity with a minimal amount of active ingredients but with convenient pesticidal properties. Researchers have been inspired to produce less toxic and target-specific nano-pesticides without compromising efficacy due to rapid research advances in nano-pesticides. Thus, targetspecific nano-pesticides should aid in reducing non-target plant damage and lowering the amount released into the atmosphere (Kumar et al. 2019b).

Bacterial tendency to reduce metal ions through active absorption has promoted their utilization for the creation of antagonistic nanoparticle synthesis for insectpest management. Several bacterial species (Bacillus sp., Corynebacterium sp., Pseudomonas sp., Shewanella sp.) have been utilized for the synthesis of NPs using various inorganic metals (e.g. $\mathrm{Ag}, \mathrm{Al}, \mathrm{Au}, \mathrm{MnO}, \mathrm{ZnO}, \mathrm{TiO}_{2}$ ) over the last two decades. The use of these bacteria-mediated NPs has improved agricultural production by reducing losses during crop processing, transportation and storage (Kumari et al. 2019). Few examples of bacteria-based nano-formulations and their applications against phytopathogens and insect-pest management are listed in Table 1.

\section{Bacillus sp. against phytopathogens and insect pest}

The microorganisms from the Bacillus group secrete various kinds of compounds with antagonistic properties which exist in various habitats. An effective compound of the antagonistic organisms can be selected based on the principle step of the biological control (Ashwini and Srividya 2014). The Bacillus species produce approximately $8 \%$ of the total secondary metabolites with antagonistic properties. The majority of the activities including siderophores, lipopeptides, bacteriocins, and polyketide compounds from the Bacillus species are synthesized non-ribosomically (Fira et al. 2018). The Bacillus species such as B. stearothermophilus, B. laterosporus, B. circulans, B. licheniformis, B. amyloliquefaciens, B. pabuli, $B$. magaterium, $B$. thuringiensis, and $B$. subtilis are known to secrete chitinase. Chitinase from the B. subtilis had 
Table 1 Bacteria-based nano-formulations (nanoparticles/lipopeptides) and their applications against phytopathogens and insectpest management

\begin{tabular}{|c|c|c|c|c|}
\hline Bacterial species & $\begin{array}{l}\text { Nano-formulation } \\
\text { nanoparticles }\end{array}$ & Target pathogen & Application & References \\
\hline $\begin{array}{l}\text { Bacillus amyloliquefaciens } \\
\text { and Bacillus subtilis- }\end{array}$ & Ag NPs & Culex pipiens pallens & $\begin{array}{l}\text { Quick effect on vector } \\
\text { mosquito and microbial } \\
\text { pathogen }\end{array}$ & Fouad et al. (2017) \\
\hline B. cereus SZT1 & AgNPs & $\begin{array}{l}\text { Xanthomonas oryzae pv. ory- } \\
\text { zae }\end{array}$ & $\begin{array}{l}\text { Effective against leaf blight } \\
\text { in rice caused by bacteria }\end{array}$ & Ahmed et al. (2020) \\
\hline B. cereus RNT6 & $\mathrm{ZnONPs}$ & $\begin{array}{l}\text { Burkholderia glumae and } B \text {. } \\
\text { gladioli }\end{array}$ & $\begin{array}{l}\text { ZnONPs could be used as } \\
\text { nano-pesticides against rice } \\
\text { panicle blight }\end{array}$ & Ahmed et al. (2021) \\
\hline B. thuringiensis & AgNPs & $\begin{array}{l}\text { Trichoplusia ni and Agrotis } \\
\text { ipsilon }\end{array}$ & $\begin{array}{l}\text { Btk-synthesised AgNP } \\
\text { showed high virulence } \\
\text { toward larvae of Trichoplu- } \\
\text { sia ni than to Agrotis ipsilon }\end{array}$ & Sayed et al. (2017) \\
\hline B. thuringiensis coated & ZnONPs & Callosobruchus maculatus & $\begin{array}{l}\text { Bt-ZnO based NPs effective } \\
\text { against Callosobruchus } \\
\text { maculatus }\end{array}$ & Malaikozhundan et al. (2017) \\
\hline B. thuringiensis & Au NPs & $\begin{array}{l}\text { Aedes aegypti and Anopheles } \\
\text { subpictus }\end{array}$ & $\begin{array}{l}\text { AuNPs and Bt toxin interac- } \\
\text { tion able to protect Bt from } \\
\text { sunlight as well as relocate } \\
\text { Bt toxin to the target site }\end{array}$ & Patil et al. (2018) \\
\hline \multirow[t]{2}{*}{$\begin{array}{l}\text { Paenibacillus polymyxa strain } \\
\text { Sx3 }\end{array}$} & $\mathrm{ZnO}, \mathrm{MnO}_{2}$, and $\mathrm{MgO}$ & $\begin{array}{l}\text { Xanthomonas oryzae pv. } \\
\text { Oryzae (Xoo) }\end{array}$ & $\begin{array}{l}\text { Combat the antibiotic resist- } \\
\text { ant of XoO }\end{array}$ & Ogunyemi et al. (2020) \\
\hline & Lipopeptides & & & \\
\hline B. amyloliquefaciens & Bacillomycin D & $\begin{array}{l}\text { F. oxysporum f. sp. cucumeri- } \\
\text { num }\end{array}$ & $\begin{array}{l}\text { Fusarium wilt control of } \\
\text { cucumber }\end{array}$ & $\begin{array}{l}\text { Koumoutsi et al. (2004), Xu } \\
\text { et al. (2013), Li et al. (2014) }\end{array}$ \\
\hline B. circulans & Iturin A & F. oxysporum f. sp. lycopersici & $\begin{array}{l}\text { Management of Fusarium } \\
\text { crown and root rot of } \\
\text { tomato }\end{array}$ & Hsieh et al. (2008) \\
\hline B. licheniformis & Surfactin & Magnaporthe grisea & $\begin{array}{l}\text { Effective against rice seed- } \\
\text { ling blight }\end{array}$ & Tendulkar et al. (2007) \\
\hline B. mojavensis & Mojavensin A & $\begin{array}{l}\text { F. oxysporum f.sp. cucumeri- } \\
\text { num, F. verticillioides and } \\
\text { Valsa mali }\end{array}$ & $\begin{array}{l}\text { Effective in Fusarium wilt } \\
\text { control of cucumber and } \\
\text { rotting and wilting of maize }\end{array}$ & Ma et al. (2012) \\
\hline B.pumilus & Pumilacidin & $\begin{array}{l}\text { Pythium aphanidermatum, } \\
\text { Rhizoctonia solani and Sclero- } \\
\text { tium rolfsii }\end{array}$ & $\begin{array}{l}\text { Effective against rotting of } \\
\text { soybean, root and stem, and } \\
\text { blights of fruits }\end{array}$ & de Melo et al. (2009) \\
\hline \multirow[t]{3}{*}{ B. subtilis } & Iturin/Fengycin & Podosphaera fusca & $\begin{array}{l}\text { Protection against powdery } \\
\text { mildew in cucurbits }\end{array}$ & $\begin{array}{l}\text { Romero et al. (2007), Meena } \\
\text { and Kanwar (2015) }\end{array}$ \\
\hline & Iturin A/Fengycin & Penicilium digitatum & $\begin{array}{l}\text { Green mold disease man- } \\
\text { agement in mandarin fruit }\end{array}$ & Waewthongrak et al. (2015) \\
\hline & Bacillomycin Ls/Fengycin & Fusarium oxysporum & Control of Fusarium wilt & Luo et al. (2015) \\
\hline B. thuringiensis & Kurstakin & $\begin{array}{l}\text { Colletotrichum gloeospori- } \\
\text { oides }\end{array}$ & $\begin{array}{l}\text { Anthracnose disease control } \\
\text { in fruits }\end{array}$ & $\begin{array}{l}\text { Kim et al. (2004), Mnif and } \\
\text { Ghribi (2015) }\end{array}$ \\
\hline B. vallismortis & Bacillomycin D & $\begin{array}{l}\text { Alternaria alternata, } \\
\text { Cryphonectria parasitica, F. } \\
\text { graminearum, Phytophthora } \\
\text { capsica, and Rhizoctonia } \\
\text { solani }\end{array}$ & $\begin{array}{l}\text { Mitigation of wheat and } \\
\text { vegetable diseases }\end{array}$ & Zhao et al. (2010) \\
\hline
\end{tabular}

premier chitinolytic actions that can degrade the chitin zones in colloidal chitin. The chitinase enzyme shows antifungal activities against Aspergillus flavus, A. niger, and Penicillium chrysogenum. The Bacillus strain BG11 secretes chitinase with some specific properties including higher production rate at stationary phase, competent monomeric degradation of chitin, less inhibition of the end product, resistance against salt and proteases, and compatibility with many pesticides as compared with the other Bacillus species (Karunya et al. 2011). The chitinase enzymes can break the hard chitin cell wall of the conidia, hyphae, sclerotia, and chlamydospores and also 
have inhibitory actions against many plant pathogens. Other species like B. cereus, B. mycoides, B. pumilus, $B$. pasteurii, $B$. sphaericus, and $B$. mojavensis including the above species are efficiently producing the antibiotic molecules with the inhibitory actions for plant pathogens by antibiosis mechanism (Cawoy et al. 2011). The strains of the $B$. subtilis named PRBS1 and AP3 had been reported for in vitro inhibition of the pathogenic fungi from the soybean seeds including species of Phomopsis, Colletotrichum truncatum, Rhizoctonia solani, Macrophomina phaseolina, and Sclerotinia sclerotiorum. Hence, B. subtilis strains are potentially used to treat pathogens of the seeds or to promote plant growth (Widnyana and Javandira 2016).

NKG1-a strain of Bacillus methylotrophicus has been used for its potential to treat fungal infections and also used as a fertilizing agent. This strain was extracted from the root area of Pinus koraiensis (Ge et al. 2016). The strain of B. subtilis $\mathrm{BC} 2$ demonstrated antagonistic activity against pathogenic fungi through the lytic process mediated by enzymes. The other studies showed that the $\mathrm{BC} 2$ strains acted as a biological controlling agent against Colletotrichum gloeosporioides (Ashwini and Srividya 2014). Under greenhouse, the native strains of the Bacillus species B19 and P12 can reduce the white mold in French beans caused by Sclerotinia sclerotiorum (Sabaté et al. 2018). The other species of the Bacillus species strains including B. amyloliquefaciens 17A-B3 and B. subtilis 30B-B6 have worked against Phytophthora infestans. Throughout the crop season, the late blight disease was notably cured by the B. subtilis strain 30B-B6 (Caulier et al. 2018). The lipopeptides from the B. subtilis can reduce the growth of pathogenic species of microbes including Aspergillus, Rhizopus, Botrytis, and Penicillium (de Andrade et al. 2019). B. thuringiensis is the widely studied species of the Bacillus group against pesticides. The insects from various orders such as Coleoptera, Diptera and Lepidoptera can be controlled biologically by using the accumulated protein crystals synthesized by B. thuringiensis (Valtierra-de-Luis et al. 2020). Chitinase enzymes secreted from the $B t$ can hydrolyze the chitin. Chitinase enzymes can enhance the insecticidal properties of Cry proteins. Bt chitinases have the potential to control nematodes, fungi, and entomopathogens and are also used to produce chitin-derived oligosaccharides that possess antibacterial properties (Martínez-Zavala et al. 2020).

\section{Bacillus sp.-based nanoparticle synthesis/ nano-formulation}

Recently in the area of biology and medicines, noble nano-formulations are preferred due to their unique morphology (shape and size) that further depends on biological, chemical, and physical factors. The synthesis of NPs has been done by using different processes based on biological, chemical, and physical approaches (Gopinath and Velusamy 2013). The most preferred methods of nanoparticle synthesis should offer superior properties of the encapsulated material and be cost-effective with no toxic hazards (Ghiuță et al. 2018). In the clinical and food sector, the chemical approach-based NPs were evaded because their toxicity came from the chemicals, which were used during formulation. The nano-formulations based on the biogenic approaches (cheap and eco-friendly) took priority due to the elimination of the chemical toxicity (Wei et al. 2012). Based on the place of nano-formulation, there are two main categories of the biosynthetic approaches-intra and extracellular synthesis. The extracellular synthesis of NPs is an emerging approach to get insights on the mode of synthesis along with down- and upstream processing. The living microorganism-based biopesticides had the potential to manage pest control (Senthil-Nathan 2015).

One of the Bacillus species strain GP23 extracted from the marine soil was used to prepare silver nanoparticles (AgNPs) by the extracellular approach which suppressed the Fusarium oxysporum was responsible for the wilt disease of legumes, banana, tobacco, cucurbits, sweet potatoes, and tomato (Gopinath and Velusamy 2013). The extracellularly synthesized AgNPs by using the SBT8 strain of Bacillus have antimicrobial properties and acted as a biocatalyst (Yurtluk et al. 2018). The NPs synthesized taking silver nitrate as precursor using $B$. subtilis and $B$. amyloliquefaciens showed antibacterial activity against both gram-positive and negative bacteria as well as antifungal actions against Candida albicans (Ghiuță et al. 2018). The nanoscale $B t$ chitinases exhibited excellent capability for the deliverance of the nematicidal preparations for managing Caenorhabditis elegans. Hence, the nanoscale $B$. thuringiensis chitinases can act as a biopesticidal delivery system to extend farming applications (Qin et al. 2020). By applying the nano-technological approach, the size of the entomopathogenic bacterium (Bt) can be reduced to formulate $B t$ nanoparticle, which was used as a biocontrol agent (Swamy and Asokan 2013). Instead of NPs, the nano-composites of $B t$ with $B t$ bioactives in various nano-formulations such as nanocapsules, nano-suspension, and nano-emulsion had been utilized as nano-pesticides (Damalas and Koutroubas 2018).

The Cry protein extracted from the $B t$ is the major component that belongs from the large families of protein possessing toxic activities with different specifications. Most of this show toxicity against dipterans, coleopterans, and lepidopterans, few of these proteins also work against nematodes and hymenopterans. The 
loading of Cry proteins to the nanomaterial for the production of the nano-composites could be easy and the bioactivity of the Cry protein was maintained by the nano-materials which also enhanced the stability (Devi et al. 2019). The nano-crystallization of the cyclic lipopeptides extracted from the $B$. subtilis enhances the stability at storage conditions by oxidation prevention and antifungal activity by controlled deliverance of the cyclic lipopeptides. These nano-crystals (solid lipid NPs) of the cyclic lipopeptides also prevent the growth of the Aspergillus carbonarius and A. niger spores and hyphae (Lin et al. 2020). The zero-valent AgNPs had been synthesized using Bacillus species strain AW1-2 to control Colletotrichum falcatum which is responsible for the red rot disease of sugarcane (Ajaz et al. 2021).

\section{Mechanisms of action of nano-particles/nano-formulation against phytopathogens}

Many variations were found in the mode of biocidal action of nano-formulations based on the employed microbes including parasitism, antibiosis, competence in rhizosphere-like stimulation, and alteration in plant growth and metabolism, respectively (Shrivastava et al. 2014). The nano-formulations are known to release bioagents from the NPs in a targeted manner. Many nanopesticides have been produced which were used to prevent the most effective plant pathogen including Phyllosticta, Phytopthora, Aspergillus, Fusarium, and Phoma species (Bhattacharyya et al. 2016). The nano-formulations can act as a plant growth promoter or disease suppressor by activating the various defense mechanisms (Malerba and Cerana 2018). The NPs acted against phytopathogens through disruption of protein, formation and antioxidant deprivation of the reactive oxygen species (ROS), membrane impermeability, and inhibition of the gene transporter. All of the above pathways were dependent on each other and acted in combination with different phytopathogens (Alkhattaf 2021).

The negative charge of the NPs and electrostatic interactions of microbial membranes can adhere to each other. The NPs and membrane depolarization have disrupted the respiratory and permeability actions of the membrane that can affect the physical properties and had disrupted the cell components of the phytopathogen that ultimately leads to cell death. The disruption of the cell membrane results in the outflow of cellular constituents such as proteins, DNA, RNA, enzymes, and metabolites. In the intra and extracellular regions of the cell wall (phytopathogens), many irregular gaps can be created by the NPs for their dispersion (Alghuthaymi et al. 2015). The damaging of the cell membrane and perforations of the cell surface caused by NPs had been observed through transmission electron microscopy. The Transmission
Electron Microscopy (TEM) observations showed the severe damage of the cell membrane with inflammation and discharge of the cytoplasmic and nuclear components resulting death of the pathogens (Ibrahim et al. 2020). The plant fungi like Trichosporon asahii and Alternaria alternata also found similar effects of AgNPs. In these species, NP toxicity can be the consequence of the formation of ROS (Xia et al. 2016). The ROS formed during the mode of action of NPs can disrupt the cell membrane and other cellular components like fat, proteins, RNA, and DNA molecules. In the cells of the Azotobacter vinelandii, the cellular damage and AgNPs had detected by the TEM and also found the hydroxyl radicals developed by the AgNPs by electron spin resonance (Alkhattaf 2021).

\section{Mechanisms of action of nano-particles/nano-formulation against insect pest}

In many nano-formulations, which had been used against the Tribolium castaneum, muscular destruction, changes in the pigmentation, epidermal thickness, and necrosis were found in the cuticle and also found in the cellular destructions among the endo and exocuticle (Hashem et al. 2018). In addition to the injury in the cuticle, the AgNPs made up of seed extract of Pedalium murex caused loss of the hairs from the head, abdomen, and antenna of the larvae of Aedes egypti (Ishwarya et al. 2017). Additionally, the AgNPs can also cause cuticle depigmentation. Moreover, the AgNPs were also reported to create stress which can increase the level of cytokines, ROS, alteration in membrane potential, and pro-inflammatory mediators (Mao et al. 2018). The impairment of the crawl and climb abilities in later and adult stages has been found if the ingestion of the AgNPs occurred in the early stages of the larva. The metabolic alterations in fat, carbohydrates, and proteins with a reduced level of fat droplets, and an enhanced level of ROS had been found in the larval tissues if the oral dosage of the AgNPs increased (Raj et al. 2017).

If the flies are treated with a nonlethal concentration of AgNPs, the depigmentation in the cuticle was found which resembled the copper starvation conditions. In this condition, the enzymatic activities of the two copper-dependent enzymes namely $\mathrm{Cu}-\mathrm{Zn}$ superoxide dismutase and tyrosinase were decreased. These enzymes augmented pigment production and antioxidant actions (Armstrong et al. 2013). The formation of ROS occurred due to the toxic components and further elevates the immune system and superoxide dismutase which helped the insect to manage the extracellular ROS (Gretscher et al. 2016). The expression of the protein calexcitin accountable for the excitement of the membrane and calcium-binding had been lowered by applying AgNPs 
(Meng et al. 2017). Other nano-formulations enhanced the activity of the acetylcholine esterase and glutathione S-transferases (Milivojevic et al. 2015). The inhibition of the protease actions had been found because of the AgNPs (Kantrao et al. 2017). The protease inactivation was occurred due to the electrostatic and hydrophobic interaction which further endorsed the protease adsorption on the NP surface that can convert the biological actions of the enzyme, for example, by impairing the binding with the substrate (Shahzad and Manzoor 2021).

\section{Effects on plant growth and promotion}

Nanoparticles hold specific physical and chemical characteristics that can alter the biochemical and physiological processes of the plant during growth and promotion. The reduced weight of the seeds and increased number of the seeds was found by applying the NPs on the shoot and root growth with the involvement of mycorrhizal fungi and growth-promoting microorganisms. The treatment of the seeds with NPs modulated the phytohormones and participation of the other cellular components during germination. The growth induction was found in the Dracocephalum moldavica plants by applying NPs (Gohari et al. 2020). Among the other species of the Bacillus, many B. subtilis strains in the form of silver, gold, and aluminium-coated NPs can significantly increase plant growth by inhibiting the phytopathogens and insect pests, hence used as potential nano-bio-fertilizers (Gouda et al. 2018). The biocontrol effect included the induction ability of the natural host plant defense system for the various phytopathogens (Lastochkina et al. 2018). Further, the formulation and storage of the $B$. subtilis strains were easy, because they can produce endospores with resistant properties against physical and chemical factors including $\mathrm{pH}$, temperature, desiccation, UV radiation, and consequently, could activate and maintain the plant host defense system under adverse circumstances. The V26 strain of the B. subtilis exhibited higher activity against phytopathogens with potential components for biocontrol and also played a vital role in plant growth and promotion (Shahzad and Manzoor 2021).

\section{Conclusion}

Bio-pesticides are gaining popularity around the world as a better way for insect-pest management with minimum risks to humans and the environment. Biopesticides based on nanotechnology provide environmentally friendly and effective pest control options that are not harmful to the environment. Biopesticides, especially nano-biopesticides, have the potential to metamorphose the global agricultural field in terms of food and feed protection. Nano-biopesticides excel because of their small size, large surface area, durability, increased effectiveness, high solubility, versatility, and low toxicity. Nano-biopesticides have the potential to reduce the toxicity of chemical pesticides, while also providing target-specific crop pest control. They may be useful in the creation of intelligent nano-systems for the reduction of agricultural problems including environmental effects, food productivity, safety and security. These nano-systems have demonstrated a high capacity for controlled-release behaviour, thereby assuring their effectiveness in long-term use with the possibility of addressing the issues of eutrophication and pesticide residues' accumulation.

But the most significant stumbling block to nanotechnological agricultural progress lies with its ethical acceptance. Farmers in India are poorly trained and do not know about nano-technological agricultural facilities. Toxicity and/or NPs accumulation in biological processes such as the food chain is another great concern. In addition, the NP-based agricultural research is of interest due to the delayed exposure of NPs in the natural system. Scientists are, therefore, trying to figure out how to respond to the acceptance of NPs and their non-absorption in a cell or system that ultimately leads to their further amplification. Hence the future research needs to target better understanding of the characterization, formulation, morphology as well as application of nano-biopesticides to apprehend their final fate in animals, humans, and plants. As a result, various aspects of nano-biopesticides, including their present status, constraints, prospects, and regulatory network, must be checked regularly to ensure their successful use for the benefit of humanity. In addition, studies investigating at molecular levels using various animal models should be focused on to fully illustrate the mode of actions involved in insect-pest management. Further, the long-term effects of the use of NPs on plants and animals should be evaluated along with their stability, quantity, and crop-specific application dosages to ensure agricultural safety and sustainability.

\section{Abbreviations \\ NPs: Nanoparticles; AgNPs: Silver nanoparticles; AuNPs: Gold nanoparticles; MgO: Magnesium nanoparticles; $\mathrm{MnO}_{2}$ : Manganese dioxide; ZnO NPs: Zinc oxide nanoparticles; Al: Aluminium; MnO: Manganese oxide; ZnO: Zinc oxide; $\mathrm{TiO}_{2}$ : Titanium dioxide; TEM: Transmission electron microscopy; ROS: Reactive oxygen species.}

\section{Acknowledgements}

All authors are highly grateful to the higher authority of the respective department, university and Institution for their support in conducting this research.

\section{Authors' contributions}

PK conceived and designed the manuscript; DKM, SP, MK and PK wrote the manuscript; PK and AM critically reviewed the manuscript and did the required editing. All authors have read and approved the manuscript. 


\section{Funding}

Author (Pradeep Kumar) would like to thanks Early Career Research Award, SERB, Government of India (file no ECR/2017/001143) for their financial support to carry out this research work.

\section{Availability of data and materials}

Not applicable.

\section{Declarations}

\section{Ethics approval and consent to participate}

Not applicable.

\section{Consent for publication}

Not applicable.

\section{Competing interests}

Authors declare that they have no competing interests.

\begin{abstract}
Author details
${ }^{1}$ Applied Microbiology Laboratory, Department of Forestry, North Eastern Regional Institute of Science and Technology, Nirjuli, Arunachal Pradesh 791109, India. ${ }^{2}$ Department of Dairy Science and Food Technology, Institute of Agricultural Sciences, Banaras Hindu University, Varanasi, Uttar Pradesh 221005, India. ${ }^{3}$ CASS Food Research Centre, School of Exercise and Nutrition Sciences, Deakin University, Burwood, VIC 3125, Australia. ${ }^{4}$ Nuclear Agriculture and Biotechnology Division, Bhabha Atomic Research Centre, Trombay, Mumbai 400085, India.
\end{abstract}

Received: 22 July 2021 Accepted: 22 September 2021 Published online: 26 September 2021

\section{References}

Ahmed T, Shahid M, Noman M, Niazi MBK, Mahmood F, Manzoor I, Zhang Y, L B, Yang Y, Yan C (2020) Silver nanoparticles synthesized by using Bacillus cereus SZT1 ameliorated the damage of bacterial leaf blight pathogen in rice. Pathogens 9(3):160

Ahmed T, Wu Z, Jiang H, Luo J, Noman M, Shahid M, Manzoor I, Allemailem KS, Alrumaihi F, Li B (2021) Bioinspired green synthesis of zinc oxide nanoparticles from a native Bacillus cereus strain RNT6: characterization and antibacterial activity against rice panicle blight pathogens Burkholderia glumae and B. gladioli. Nanomaterials 11(4):884

Ajaz S, Ahmed T, Shahid M, Noman M, Shah AA, Mehmood MA, Abbas A, Cheema Al, labal MZ, Li B (2021) Bioinspired green synthesis of silver nanoparticles by using a native Bacillus sp. strain AW1-2: Characterization and antifungal activity against Colletotrichum falcatum Went. Enzyme Microb Technol 144:109745

Alghuthaymi MA, Almoammar H, Rai M, Said-Galiev E, Abd-Elsalam KA (2015) Myconanoparticles: synthesis and their role in phytopathogens management. Biotechnol Biotechnol Equip 29(2):221-236

Ali M, Ahmed T, Wu W, Hossain A, Hafeez R, Islam Masum M, Wang Y, An Q, Sun G, Li B (2020) Advancements in plant and microbe-based synthesis of metallic nanoparticles and their antimicrobial activity against plant pathogens. Nanomaterials 10(6):1146

Alkhattaf FS (2021) Gold and silver nanoparticles: green synthesis, microbes, mechanism, factors, plant disease management and environmental risks. Saudi J Biol Sci 28(6):3624-3631. https://doi.org/10.1016/j.sjbs.2021.03. 078

Armstrong N, Ramamoorthy M, Lyon D, Jones K, Duttaroy A (2013) Mechanism of silver nanoparticles action on insect pigmentation reveals intervention of copper homeostasis. PLOS ONE 8(1):e53186

Ashwini N, Srividya S (2014) Potentiality of Bacillus subtilis as biocontrol agent for management of anthracnose disease of chilli caused by Colletotrichum gloeosporioides OGC1. 3 Biotech 4(2):127-136

Bhattacharyya A, Duraisamy P, Govindarajan M, Buhroo AA, Prasad R (2016) Nano-biofungicides: emerging trend in insect pest control. In: Advances and applications through fungal nanobiotechnology. Springer, pp 307-319

Caulier S, Gillis A, Colau G, Licciardi F, Liépin M, Desoignies N, Modrie P, Legrève A, Mahillon J, Bragard C (2018) Versatile antagonistic activities of soilborne Bacillus spp. and Pseudomonas spp. against Phytophthora infestans and other potato pathogens. Front Microbiol 9:143

Cawoy H, Bettiol W, Fickers P, Ongena M (2011) Bacillus-based biological control of plant diseases. In: Pesticides in the modern world-pesticides use and management. InTech, pp 273-302

Damalas CA, Koutroubas SD (2018) Current status and recent developments in biopesticide use. Agriculture 8(1):13

de Andrade FM, de Assis PT, Souza TP, Guimarães PHS, Martins AD, Schwan RF, Pasqual M, Dória J (2019) Beneficial effects of inoculation of growthpromoting bacteria in strawberry. Microbiol Res 223:120-128

de Melo FMPD, Fiore MF, Moraes LABD, Silva-Stenico ME, Scramin S, Teixeira MDA, Melo ISD (2009) Antifungal compound produced by the cassava endophyte Bacillus pumilus MAllIM4A. Sci Agric 66(5):583-592

Devi PV, Duraimurugan P, Chandrika KSVP (2019) Bacillus thuringiensis-based nanopesticides for crop protection. In: Nano-biopesticides today and future perspectives. Elsevier, pp 249-260

Fira D, Dimkić I, Berić T, Lozo J, Stanković S (2018) Biological control of plant pathogens by Bacillus species. J Biotechnol 285:44-55

Fouad H, Hongjie L, Yanmei D, Baoting Y, El-Shakh A, Abbas G, Jianchu M (2017) Synthesis and characterization of silver nanoparticles using Bacillus amyloliquefaciens and Bacillus subtilis to control filarial vector Culex pipiens pallens and its antimicrobial activity. Artif Cells Nanomed Biotechnol 45(7):1369-1378

Ge B, Liu B, Nwet TT, Zhao W, Shi L, Zhang K (2016) Bacillus methylotrophicus strain NKG-1, isolated from Changbai Mountain, China, has potential applications as a biofertilizer or biocontrol agent. PLOS ONE 11(11):e0166079

Ghiuță I, Cristea D, Croitoru C, Kost J, Wenkert R, Vyrides I, Anayiotos A, Munteanu D (2018) Characterization and antimicrobial activity of silver nanoparticles, biosynthesized using Bacillus species. Appl Surf Sci 438:66-73

Gohari G, Mohammadi A, Akbari A, Panahirad S, Dadpour MR, Fotopoulos $\checkmark$, Kimura S (2020) Titanium dioxide nanoparticles $\left(\mathrm{TiO}_{2} \mathrm{NPS}\right.$ ) promote growth and ameliorate salinity stress effects on essential oil profile and biochemical attributes of Dracocephalum moldavica. Sci Rep 10(1):1-14

Gopinath V, Velusamy P (2013) Extracellular biosynthesis of silver nanoparticles using Bacillus sp. GP-23 and evaluation of their antifungal activity towards Fusarium oxysporum. Spectrochim Acta A Mol Biomol SpectrosC 106:170-174

Gouda S, Kerry RG, Das G, Paramithiotis S, Shin H-S, Patra JK (2018) Revitalization of plant growth promoting rhizobacteria for sustainable development in agriculture. Microbiol Res 206:131-140

Gretscher RR, Streicher PE, Strauß AS, Wielsch N, Stock M, Wang D, Boland W, Burse A (2016) A common theme in extracellular fluids of beetles: extracellular superoxide dismutases crucial for balancing ROS in response to microbial challenge. Sci Rep 6(1):1-13

Hashem A, Alqarawi AA, Radhakrishnan R, Al-Arjani A-BF, Aldehaish HA, Egamberdieva D, Abd-Allah EF (2018) Arbuscular mycorrhizal fungi regulate the oxidative system, hormones and ionic equilibrium to trigger salt stress tolerance in Cucumis sativus L. Saudi J Biol Sci 25(6):1102-1114

Hsieh FC, Lin TC, Meng M, Kao SS (2008) Comparing methods for identifying Bacillus strains capable of producing the antifungal lipopeptide iturin A. Curr Microbiol 56(1):1-5

Ibrahim IM, Abdelmalek DH, Elshahat ME, Elfiky AA (2020) COVID-19 spike-host cell receptor GRP78 binding site prediction. J Infect 80(5):554-562

Ishwarya R, Vaseeharan B, Anuradha R, Rekha R, Govindarajan M, Alharbi NS, Kadaikunnan S, Khaled JM, Benelli G (2017) Eco-friendly fabrication of Ag nanostructures using the seed extract of Pedalium murex, an ancient Indian medicinal plant: histopathological effects on the Zika virus vector Aedes aegypti and inhibition of biofilm-forming pathogenic bacteria. J Photochem Photobiol B: Biol 174:133-143

Kachhawa D (2017) Microorganisms as a biopesticides. J Entomol Zool Stud 5(3):468-473

Kantrao S, Ravindra MA, Akbar S, Jayanthi PK, Venkataraman A (2017) Effect of biosynthesized Silver nanoparticles on growth and development of Helicoverpa armigera (Lepidoptera: Noctuidae): Interaction with midgut protease. J Asia Pac Entomol 20(2):583-589 
Karunya SK, Reetha D, Saranraj P, Milton DJ (2011) Optimization and purification of chitinase produced by Bacillus subtilis and its antifungal activity against plant pathogens. Int J Pharm Biol Arch 2(6):1680-1685

Keswani C, Singh HB, García-Estrada C, Caradus J, He Y-W, MezaacheAichour S, Glare TR, Borriss R, Sansinenea E (2020) Antimicrobial secondary metabolites from agriculturally important bacteria as nextgeneration pesticides. Appl Microbiol Biotechnol 104(3):1013-1034

Kim PI, Bai H, Bai D, Chae H, Chung S, Kim Y, Park R, Chi YT (2004) Purification and characterization of a lipopeptide produced by Bacillus thuringiensis CMB26. J Appl Microbiol 97(5):942-949

Köhl J, Kolnaar R, Ravensberg WJ (2019) Mode of action of microbial biological control agents against plant diseases: relevance beyond efficacy. Front Plant Sci 10:845. https://doi.org/10.3389/fpls.2019.00845

Koumoutsi A, Chen XH, Henne A, Liesegang H, Hitzeroth G, Franke P, Vater J, Borriss R (2004) Structural and functional characterization of gene clusters directing nonribosomal synthesis of bioactive cyclic lipopeptides in Bacillus amyloliquefaciens strain FZB42. J Bacteriol 186(4):1084-1096

Kumar KK, Sridhar J, Murali-Baskaran RK, Senthil-Nathan S, Kaushal P, Dara SK, Arthurs S (2019a) Microbial biopesticides for insect pest management in India: Current status and future prospects. J Invertebr Pathol 165:74-81

Kumar S, Nehra M, Dilbaghi N, Marrazza G, Hassan AA, Kim K-H (2019b) Nano-based smart pesticide formulations: Emerging opportunities for agriculture. J Control Release 294:131-153

Kumari B, Mallick M, Solanki MK, Hora A, Mani M (2019) Applying nanotechnology to bacteria: an emerging technology for sustainable agriculture. In: Role of plant growth promoting microorganisms in sustainable agriculture and nanotechnology. Elsevier, pp 121-143

Lastochkina OV, Pusenkova LI, Yuldashev RA, llyasova EY, Aliniaeifard S (2018) Effect of Bacillus subtilis based micrrobials on physiological and biochemical parameters of sugar beet (Beta vulgaris L.) plants infected with Alternaria alternata. Selskokhoziaistvennaya Biol 53(5):958-968

Li B, Li Q, Xu Z, Zhang N, Shen Q, Zhang R (2014) Responses of beneficial Bacillus amyloliquefaciens SQR9 to different soilborne fungal pathogens through the alteration of antifungal compounds production. Front Microbiol 5:636

Lin N, Wang C, Ding J, Su L, Xu L, Zhang B, Zhang Y, Fan J (2020) Efficacy of nanoparticle encapsulation on suppressing oxidation and enhancing antifungal activity of cyclic lipopeptides produced by Bacillus subtilis. Colloids Surf B: Biointerfaces 193:111143

Luo C, Liu X, Zhou H, Wang X, Chen Z (2015) Nonribosomal peptide synthase gene clusters for lipopeptide biosynthesis in Bacillus subtilis 916 and their phenotypic functions. Appl Environ Microbiol 81(1):422-431

Ma Z, Wang N, Hu J, Wang S (2012) Isolation and characterization of a new iturinic lipopeptide, mojavensin A produced by a marine-derived bacterium Bacillus mojavensis B0621A. J Antibiot 65(6):317-322

Malaikozhundan B, Vaseeharan B, Vijayakumar S, Thangaraj MP (2017) Bacillus thuringiensis coated zinc oxide nanoparticle and its biopesticidal effects on the pulse beetle, Callosobruchus maculatus. J Photochem Photobiol B: Biol 174:306-314

Malerba M, Cerana R (2018) Recent advances of chitosan applications in plants. Polymers 10(2):118

Mampallil LJ, Faizal MH, Anith KN (2017) Bacterial bioagents for insect pest management. J Entomol Zool Stud 5(6):2237-2244

Mao B-H, Chen Z-Y, Wang Y-J, Yan S-J (2018) Silver nanoparticles have lethal and sublethal adverse effects on development and longevity by inducing ROS-mediated stress responses. Sci Rep 8(1):1-16

Martínez-Zavala SA, Barboza-Pérez UE, Hernández-Guzmán G, Bideshi DK, Barboza-Corona JE (2020) Chitinases of Bacillus thuringiensis: Phylogeny, modular structure, and applied potentials. Front Microbiol 10:3032

Meena KR, Kanwar SS (2015) Lipopeptides as the antifungal and antibacterial agents: applications in food safety and therapeutics. BioMed Res Int. https://doi.org/10.1155/2015/473050

Meng X, Abdlli N, Wang N, Lü P, Nie Z, Dong X, Lu S, Chen K (2017) Effects of Ag nanoparticles on growth and fat body proteins in silkworms (Bombyx mori). Biol Trace Elem Res 180(2):327-337

Milivojevic B, Vicente-Grabovetsky A, Doeller CF (2015) Insight reconfigures hippocampal-prefrontal memories. Curr Biol 25(7):821-830

Mnif I, Ghribi D (2015) Potential of bacterial derived biopesticides in pest management. Crop Prot 77:52-64
Ogunyemi SO, Zhang M, Abdallah Y, Ahmed T, Qiu W, Ali M, Yan C, Yang Y, Chen J, Li B (2020) The bio-synthesis of three metal oxide nanoparticles $\left(\mathrm{ZnO}, \mathrm{MnO}_{2}\right.$, and $\left.\mathrm{MgO}\right)$ and their antibacterial activity against the bacterial leaf blight pathogen. Front Microbiol 11:3099

Patibanda AK, Ranganathswamy M (2018) Effect of agrichemicals on biocontrol agents of plant disease control. In: Microorganisms for green revolution. Springer, pp 1-21

Patil SV, Patil CD, Narkhede CP, Suryawanshi RK, Koli SH, Shinde L, Mohite BV (2018) Phytosynthesized gold nanoparticles-Bacillus thuringiensis (BtGNP) formulation: a novel photo stable preparation against mosquito larvae. J Clust Sci 29(4):577-583

Qin J, Tong Z, Zhan Y, Buisson C, Song F, He K, Nielsen-LeRoux C, Guo S (2020) A Bacillus thuringiensis chitin-binding protein is involved in insect peritrophic matrix adhesion and takes part in the infection process. Toxins 12(4):252

Raj A, Shah P, Agrawal N (2017) Dose-dependent effect of silver nanoparticles (AgNPs) on fertility and survival of Drosophila: An in-vivo study. PLOS ONE 12(5):e0178051

Romero D, de Vicente A, Rakotoaly RH, Dufour SE, Veening JW, Arrebola E, Cazorla FM, Kuipers OP, Paquot M, Pérez-García A (2007) The iturin and fengycin families of lipopeptides are key factors in antagonism of Bacillus subtilis toward Podosphaera fusca. Mol Plant Microbe Interact 20(4):430-440

Sabaté DC, Brandan CP, Petroselli G, Erra-Balsells R, Audisio MC (2018) Biocontrol of Sclerotinia sclerotiorum (Lib.) de Bary on common bean by native lipopeptide-producer Bacillus strains. Microbiol Res 211:21-30

Sayed AMM, Kim S, Behle RW (2017) Characterisation of silver nanoparticles synthesised by Bacillus thuringiensis as a nanobiopesticide for insect pest control. Biocontrol Sci Technol 27(11):1308-1326

Senthil-Nathan S (2015) A review of biopesticides and their mode of action against insect pests. In: Thangavel P, Sridevi G (eds) Environmental sustainability. Springer, Berlin. https://doi.org/10.1007/ 978-81-322-2056-5_3

Shahzad K, Manzoor F (2021) Nanoformulations and their mode of action in insects: a review of biological interactions. Drug Chem Toxicol 44(1):1-11

Sharma M, Tarafdar A, Ghosh R, Gopalakrishanan S (2017) Biological control as a tool for eco-friendly management of plant pathogens. In: Advances in soil microbiology: recent trends and future prospects. Springer, pp 153-188

Shrivastava D, Singhai AK, Yadav RK (2014) Effect of lime and rice husk ash on engineering properties of black cotton soil. Int J Eng Res Sci Technol 3(2):292-296

Swamy HM, Asokan R (2013) Bacillus thuringiensis as 'nanoparticles'-a perspective for crop protection. Nanosci Nanotechnol-Asia 3(1):102-105

Syed Ab Rahman SF, Singh E, Pieterse CMJ, Schenk PM (2018) Emerging microbial biocontrol strategies for plant pathogens. Plant Sci 267:102-111

Tendulkar SR, Saikumari YK, Patel V, Raghotama S, Munshi TK, Balaram P, Chattoo BB (2007) Isolation, purification and characterization of an antifungal molecule produced by Bacillus licheniformis BC98, and its effect on phytopathogen Magnaporthe grisea. J Appl Microbiol 103(6):2331-2339

Valtierra-de-Luis D, Villanueva M, Berry C, Caballero P (2020) Potential for Bacillus thuringiensis and other bacterial toxins as biological control agents to combat dipteran pests of medical and agronomic importance. Toxins 12(12):773

Waewthongrak W, Pisuchpen S, Leelasuphakul W (2015) Effect of Bacillus subtilis and chitosan applications on green mold (Penicilium digitatum Sacc.) decay in citrus fruit. Postharvest Biol Technol 99:44-49

Wei X, Luo M, Li W, Yang L, Liang X, Xu L, Kong P, Liu H (2012) Synthesis of silver nanoparticles by solar irradiation of cell-free Bacillus amyloliquefaciens extracts and $\mathrm{AgNO}_{3}$. Bioresour Technol 103(1):273-278

Widnyana IK, Javandira C (2016) Activities Pseudomonas spp. and Bacillus sp. to stimulate germination and seedling growth of tomato plants. Agric Agric Sci Procedia 9:419-423

Xia L, Xia Y, Li B, Wang J, Wang S, Zhou W, Yan X (2016) Integrating agronomic practices to reduce greenhouse gas emissions while increasing the economic return in a rice-based cropping system. Agric Ecosyst Environ 231:24-33 
Xu Z, Shao J, Li B, Yan X, Shen Q, Zhang R (2013) Contribution of bacillomycin D in Bacillus amyloliquefaciens SQR9 to antifungal activity and biofilm formation. Appl Environ Microbiol 79(3):808-815

Yurtluk T, Akçay FA, Avcı A (2018) Biosynthesis of silver nanoparticles using novel Bacillus sp SBT8. Prep Biochem Biotechnol 48(2):151-159.

Zhao Z, Wang Q, Wang K, Brian K, Liu C, Gu Y (2010) Study of the antifungal activity of Bacillus vallismortis ZZ185 in vitro and identification of its antifungal components. Bioresour Technol 101(1):292-297

\section{Publisher's Note}

Springer Nature remains neutral with regard to jurisdictional claims in published maps and institutional affiliations.

\section{Submit your manuscript to a SpringerOpen ${ }^{\circ}$ journal and benefit from:}

- Convenient online submission

- Rigorous peer review

- Open access: articles freely available online

- High visibility within the field

- Retaining the copyright to your article

Submit your next manuscript at $\boldsymbol{\nabla}$ springeropen.com 